\title{
Copper, Lead and Zinc Concentration in Water, Sediments and Catfish (Clarias macrocephalus Gunther) from Butuanon River, Metro Cebu, Philippines
}

\author{
Ma. Kristina M. Oquiñena-Paler ${ }^{1}$ and Rico Ancog ${ }^{2}$ \\ ${ }^{I}$ Department of Biology, University of San Carlos, Talamban, Cebu City, 6000, Philippines \\ ${ }^{2}$ School of Environmental Science and Management, University of the Philippines Los Baños College, Los \\ Banos, Laguna 4031, Philippines
}

\begin{abstract}
Copper, lead and zinc contamination is a serious hazard. In this study, the concentration of these metals were determined by Atomic Absorption Spectroscopy in the water, sediment and in the muscle, liver and gills of catfish (Clarias macrocephalus) collected from three sampling stations of Butuanon River, Metro Cebu, Philippines. Water analysis results showed that no station exceeded the Philippines DAO 34 Series of 1990 standard at 0.05ppm both for $\mathrm{Cu}$ and $\mathrm{Pb}$. Both $\mathrm{Cu}$ and $\mathrm{Zn}$ concentration in sediments showed no significant difference but $\mathrm{Pb}$ concentration tends to increase from upstream to downstream station without exceeding the Kloke's Maximum Allowable Limit at 100ppm. The Pb concentration in C. macrocephalus from downstream station exceeded Europe's Maximum Allowable Limit in fishes set at 2ppm. All metals are concentrated in the organs in this order liver $>$ gills $>$ muscle. The Biota-Sediment Accumulation Factor (BSAF) values for organisms are within noncritical range of 0.270 to 1.819. Using regression analysis, metal concentrations in the sediment were found to positively affect the metal concentration in catfish opposite to that of the water. Organic matter negatively affects $\mathrm{Cu}$ concentration. Results indicate that $\mathrm{Zn}$ is naturally abundant in Butuanon River, while Pb and $\mathrm{Cu}$ are introduced through industrial and agricultural activities.
\end{abstract}

Keywords: Butuanon River, Clarias macrocephalus, contamination, trace metals, water quality

\section{Introduction}

Trace metals naturally occur in low concentrations in a given system [1,2] but anthropogenic activities such as unregulated industrialization saturate these in the water, air and soil [2,3]. An abnormal increase in metal concentration in these spheres could disrupt ecosystem function [1] and the dynamic equilibrium between environment and the organism [1]. Bioaccumulation occurs when organisms are exposed to polluted environment or through contaminated food $[3,4]$. Contaminants may accumulate in the bodies of organisms once they are taken up and stored faster than they are metabolized or excreted [1]. Once concentrated in the body of an organism they may be passed on through trophic transfer and could eventually reach the top of the food chain such as humans. Bioaccumulation of trace metals may lead to various diseases among different organisms including death $[3,5]$.

Butuanon River is of one of Metro Cebu's major water bodies [6,7]. Due to its status and importance to the island, it was among the sites under the United States-Asia Environmental Partnerships Program from 19961999 that initiated a management plan to rehabilitate the Butuanon Watershed in collaboration with local organizations. However, recent studies show that it is heavily polluted being the sink of domestic and industrial wastewater of the city $[8,9]$ and metals are present in its water and sediment on considerable amounts $[6,7$,$] .$ Specifically the highest concentrations recorded were that of copper $(\mathrm{Cu})$, lead $(\mathrm{Pb})$ and zinc $(\mathrm{Zn})[6,7]$.

The potential accumulation of these metals in the organisms inhabiting the Butuanon River [10] has never been assessed. People fish along the Butuanon River for household consumption [9] and for commercial purposes. Using the catfish (Clarias macrocephalus) as a bioindicator [4], it is the aim of this study to determine if this fish has accumulated $\mathrm{Cu}, \mathrm{Pb}$ and $\mathrm{Zn}$ from its ambient environment and if it is safe for human consumption.

\section{The Study Site and the Sampling Stations}

\section{Materials and Methods}

Butuanon River starts at Brgy. Sirao, Cebu City passing through adjacent Manduae City and eventually opens to the Mactan Channel. The headwaters of the Butuanon River originated from the upland areas of Cebu City that is characterized by extensive farming of large scale mango production and cutflower cultivation, patches of grassland and thin secondary forest [9]. It is a channel of slow moving water of about $5-10 \mathrm{~m}$ in width that stretches as far as $10 \mathrm{~km}$. with some portions of the river drying up during the dry season. If the upstream portions of Butuanon River is characterized by agricultural activities, it's midstream and downstream 
portion is characterized by intensive urban sprawl such as residential, commercial and industrial establishments These industries discharge their wastewater into the river, however not all of these employ a wastewater treatment facility and even those with the wastewater treatment facility, some are ill-managed [9].

Three stations were established for this study based on the water quality as indicated from previous studies which used BOD, DO and metal concentration in the water as parameters [8,9]. These three stations also differ in terms of elevation and land use. Upstream is the least polluted and is a residential area although it is preceded with agricultural land. Midstream has a deteriorating water quality [8,9] has high industrial activity such that 6 out of the 10 furniture industries discharging waste in the river are situated within the midstream station. Near this station is also a paint and thinner production facility, 2 gas stations and 2 oxygen-acetylene production facilities. The rest of the industries concentrate in the downstream area as it moves toward the mouth of the river. Downstream has the most deteriorated water quality and as of 2010, the downstream station has 13 food and feed production facilities, 4 galvanized iron producers, 3 aluminum production facilities, 3 concrete mix facility, and 2 each of the furniture industry, gas station, car service station, supermarket and 1 used oil treatment facility [http://mandauecity.gov.ph]. All of these facilities, except for the food and feed industries, have the potential to discharge metals [11].

Water, sediments and C. macrocephalus were sampled for two consecutive months particularly on December 2010 and January 2011. The pH, organic matter content and grain size of sediments were also determined since these could affect the solubility and mobility of trace metals $[11,12]$.

\subsection{Water Sampling and Analysis}

Water samples were collected using $10 \%(\mathrm{v} / \mathrm{v}) \mathrm{HNO}_{3}$ acid washed polyethelene plastic bottle. About 1 gallon of water samples were collected from each station. The samples were added with $5 \mathrm{~mL}$ nitric acid and were transported to the laboratory for digestion and analysis. About $500 \mathrm{~mL}$ of the sample were transferred to a beaker added with $3 \mathrm{ml}$ nitric acid, $\mathrm{pH}$ adjusted to less than 2 , heated and evaporated to a volume between 10 to $15 \mathrm{~mL}$ before precipitation occurs. Samples were then filtered using Whatman \#5. The filtrate was placed in a $25 \mathrm{~mL}$ volumetric flask which was diluted to volume. The solution was then exposed to Flame Atomic Absorption Spectroscopy (FAAS) (Shimadzu) for the determination of $\mathrm{Cu}, \mathrm{Pb}$ and $\mathrm{Zn}$ concentration $[6,13]$.

\subsection{Sediment Sampling and Analysis}

On site analysis of the $\mathrm{pH}$ of the sediment was conducted using a soil $\mathrm{pH}$ meter. Core samples of at least 1 meter depth were collected using an auger. The inclusion of subsoil horizons is the ideal depth for a study on elemental leaching [2]. A total of 15 core samples were collected covering the middle of the stream and both sides of the riverbanks. The composite sample from each station was packed in polyethylene bags, chilled and transported within the day to the laboratory for analysis. Samples were homogenized, air dried and oven dried at $110^{\circ} \mathrm{C}$ for three hours. The samples were divided into three for three types of analysis namely, grain size analysis, organic matter content analysis and metal content analysis $[14,15,13]$ respectively. The samples were sieved using a sieve plate $(0.002 \mathrm{~mm})$ as sediments at this particular size and lower are considered silt [14]. The dried samples were weighed $\left(\mathrm{W}_{1}\right)$ and exposed to $600^{\circ} \mathrm{C}$ muffle furnace to obtain pure inorganic matter. This was weighed $\left(\mathrm{W}_{2}\right)$ and the computation was made to determine the organic matter content $(\mathrm{OM})$ content $[15]$ :

$$
\mathrm{OM}=\quad \frac{\left(\mathrm{W}_{1}-\mathrm{W}_{2}\right)}{\mathrm{W}_{1}} \quad \times 100 \%
$$

Approximately 1 gram of sediment samples were placed in a preweighed Teflon vessel and was added with analytical grade reagents, $7 \mathrm{ml} 65 \% \mathrm{HNO}_{3}$ and $1 \mathrm{ml} 30 \% \mathrm{H}_{2} \mathrm{O}_{2}$ and digested using a microwave (Milestone ETHOS labstation) set at the following parameters: 1000 watts 10 mins. at $200^{\circ} \mathrm{C}$ then 20 min at $20^{\circ}$. After digestion samples were diluted to volume of $25 \mathrm{ml}$ and exposed to FAAS for the determination of $\mathrm{Cu}, \mathrm{Pb}$ and $\mathrm{Zn}$ concentration.

\subsection{Catfish Sampling and Analysis}

Ten catfishes (Clarias macrocephalus) were randomly collected from each sampling station per sampling, a total of 60 catfishes were collected across sampling periods in all stations. Specimens were properly labeled, packed in an aluminum foil, chilled and transported to the laboratory for analysis. Initial weight and length of the samples were measured. Samples were pooled into two groups of five. This was necessary to obtain the minimum required weight for digestion which is $1 \mathrm{~g}$. Samples were dissected to separate the gills, liver and muscle [16]. Length and weight measurement were likewise recorded. The organs were placed in a petri dish to dry at $120^{\circ} \mathrm{C}$ until reaching constant weight. Samples were placed in a preweighed Teflon vessel added with analytical grade reagents, $7 \mathrm{ml} 65 \% \mathrm{HNO}_{3}$ and $1 \mathrm{ml} 30 \% \mathrm{H}_{2} \mathrm{O}_{2}$ and digested using a microwave (Milestone ETHOS labstation) set at the following parameters: 1000 watts 10 mins. at $200^{\circ} \mathrm{C}$ then 20 min at $20^{\circ}$. Digested samples were diluted to volume of $25 \mathrm{ml}$ and exposed to FAAS for the determination of $\mathrm{Cu}, \mathrm{Pb}$ and $\mathrm{Zn}$ concentration. 
Computation was made to obtain the actual metal concentration in all samples using the following equation [6]:

(2) where: $\mu \mathrm{g} \mathrm{metal} / \mathrm{l}=\mathrm{CX} \mathrm{F}$

$$
\begin{aligned}
& \mathrm{C}=\text { metal concentration as read directly AAS } \\
& \mathrm{F}=\text { Dilution Factor }
\end{aligned}
$$

\subsection{Data Analysis}

$\mathrm{The} \mathrm{Cu}, \mathrm{Pb}$ and $\mathrm{Zn}$ loads in the water and sediments were compared with the Philippines' Department of Environment and Natural Resources Administrative (DAO) 34-1990 standard [http://www.denr.gov.ph] while that of the sediments were compared with the Kloke's Values [14]. Copper, lead and zinc concentration in the catfish (C. macrocephalus) was compared with international standards particularly that of Europe to conclude if it is safe or toxic for human consumption [17]. Metal concentration in sediments and fishes had to be compared with international standards due to the unavailability of such standards in the Philippines.

The Minitab Statistical software was used to process all data. The MANOVA was used to determine if there were statistically significant differences on the heavy metal loads of the water, sediments and organisms among the different sampling periods and stations and as well as among the different organs of the catfish $(C$. macrocephalus). The Tukey's HSD was used as post hoc test.

To determine the predictive bioaccumulation levels of $C$. macrocephalus, two assessment methods were employed; namely the computation of the Biota-Sediment Accumulation Factor (BSAF) and through regression method. The BSAF is an expression of the relationship between sediment and tissue. It was computed to determine the degree of accumulation of $\mathrm{Cu}, \mathrm{Pb}$ and $\mathrm{Zn}$ of the organism in comparison to the sediment through the equation [18]:

$\mathrm{BSAF}=$ metal concentration in the organism

metal concentration in the sediment

The BSAF values were calculated for each pair of observations and then averaged. It is interpreted to mean that the higher the BSAF, the higher is the degree of accumulation. Additionally, this study having more than one independent variable, multiple regression was used to establish the best predictor variables in the concentration of $\mathrm{Cu}, \mathrm{Pb}$ and $\mathrm{Zn}$ in the $\mathrm{C}$. macrocephalus which could be utilized by future studies focusing on the Butuanon River as these equations would provide the relationship of metal concentration in the organism with several independent variables. Multiple regression is a straightforward way to accommodate ancillary variables [20].

\section{Results}

The bioavailability of metals once introduced to the water and sediments particularly in a river ecosystem are affected by several factors such as $\mathrm{pH}$, siltation and organic matter. Sediments sampled from Butuanon River have $\mathrm{pH}$ values consistently neutral across the three sampling stations and registered no significant difference $(\mathrm{p}>0.05)$ (Table 1). Both the percentage silt and percentage organic matter follows an increasing trend from upstream to downstream portions The values of percentage of silt registered a significant difference $(p<0.05)$ across stations. On the other hand, percent organic matter content registered a significant difference $(p<0.05)$ between upstream and downstream stations while midtstream station has neither a significant difference with upstream and downstream stations.

Table 1. Physical parameters of sediments from Butuanon River

\begin{tabular}{|l|l|l|l|l|}
\hline $\begin{array}{l}\text { Sampling } \\
\text { Stations }\end{array}$ & Key Industry & $\mathbf{p H}$ & \% Silt & \% Organic Matter \\
\hline Upstream & $\begin{array}{l}\text { None but preceeded with } \\
\text { agricultural areas }\end{array}$ & $7.1 \pm 0.3$ & $31.46 \pm 0.42$ & $3.365 \pm 0.505$ \\
\hline Midstream & $\begin{array}{l}\text { Furniture, Paint-thinner, Gas } \\
\text { Station }\end{array}$ & $7.0 \pm 0.1$ & $39.19 \pm 2.26$ & $4.692 \pm 1.470$ \\
\hline Downstream & $\begin{array}{l}\text { Food and Feeds, Galvanized } \\
\text { Iron, Aluminum }\end{array}$ & $7.1 \pm 0.2$ & $45.25 \pm 0.87$ & $5.375 \pm 0.526$ \\
\hline
\end{tabular}

Notes: Values are Mean \pm Standard Deviation

The Department of Environment and Natural Resources Administrative Order 34-1990 sets the maximum allowable limits for natural waters in the Philippines. This guideline has established the regulatory standards for $\mathrm{Cu}$ and $\mathrm{Pb}$ but not for $\mathrm{Zn}$ for a Class $\mathrm{C}$ Body of water. Butuanon River however belongs to the Class D and has no established standards for physico-chemical and biological properties. This difference in classification is based on water use. Class $\mathrm{C}$ is intended for fishery production, boating and industrial supply while Class $\mathrm{D}$ is intended for agriculture, irrigation, livestock watering and industrial supply. In the case of river sediments, comparison was made with the standards established by Kloke [14]. 
The $\mathrm{Cu}$ concentration in the water of Butuanon River is confirmed to be within the acceptable standard at $0.05 \mathrm{ppm}$ and no significant difference $(\mathrm{p}>0.05)$ was noted among stations. On the other hand, $\mathrm{Cu}$ concentration in the sampled sediments of Butuanon River has exceeded the natural content interval at $20 \mathrm{ppm}$ but not in terms of maximum allowable limit set at $100 \mathrm{ppm}$. In terms of $\mathrm{Pb}$ concentration, the results indicate that the water from downstream station is significantly higher $(p<0.05)$ than that of upstream and midstream stations. The $\mathrm{Pb}$ content of water in all stations in Butuanon River passed the standard set by DENR at $0.05 \mathrm{ppm}$. However, the $\mathrm{Pb}$ concentrations in sediments of Butuanon River were found to have exceeded the natural content interval at $20 \mathrm{ppm}$ though is still within the maximum allowable limit at $100 \mathrm{ppm}$. Comparing the three stations, $\mathrm{Pb}$ concentration in the sediments indicated that downstream station is significantly higher $(\mathrm{p}<0.05)$ compared upstream but not with the midstream station. The station midstream likewise is not significantly different upstream. The $\mathrm{Zn}$ concentration in the water and sediment sampled from Butuanon River has no significant difference $(\mathrm{p}<0.05)$ among the stations (Table 2). Zinc in water for Class D bodies of water has no established standard but its load in the sediment indicates that there could potentially be an anthropogenic introduction since it has exceeded the natural background level at 50ppm. It has been observed, however, that $\mathrm{Zn}$ concentration values in the sediments of Butuanon River is still within the maximum allowable limit at 300 ppm set by Kloke [14].

If an ambient environment is contaminated with metals, there is a huge chance that an organism would likewise accumulate the metals [3]. Given that $\mathrm{Cu}, \mathrm{Pb}$ and $\mathrm{Zn}$ are present in the Butuanon River, results of this study confirm that the catfish from this river, C. macrocephalus has accumulated these metals in its organs, liver, gills and muscle at varying concentrations. Table 2 shows that the $\mathrm{Cu}$ concentration in the liver, gills and muscle of C. macrocephalus from Butuanon River is within the European standard at $20 \mathrm{ppm}$ (17) and following this order liver $>$ gills $>$ muscle. Only the liver among the organs showed a significant difference $(p<0.05)$ among the stations such that samples downstream is significantly lower compared to samples taken upstream and midstream. Lead was not detected in the organs of C. macrocephalus from stations upstream and midstream. This however will not prove if the fish sampled upstream and midstream has passed the European standard at $2 \mathrm{ppm}$ [17] since the method detection level is at $2.7 \mathrm{ppm}$. Sampled fish from downstream station clearly indicate though that it has exceeded the allowable limit and is therefore not safe for consumption. In terms of $\mathrm{Zn}$, no significant difference $(\mathrm{p}<0.5)$ among the fish organs were observed although the concentration is in this order liver $>$ gills $>$ muscle.

An implicit assumption of the BSAF approach is that there is a proportional relationship between the concentrations in sediment and tissues of living organisms. That is, if the sediment contaminant concentration doubles, the tissue contaminant concentration is also expected to double [20]. Table 3 shows that BSAF of metals in C. macrocephalus is in the following order, $\mathrm{Zn}>\mathrm{Cu}>\mathrm{Pb}$.

Table 2. Metal concentration of water, sediments and in liver, gills and muscle of C. macrocephalus from Butuanon River

\begin{tabular}{|c|c|c|c|c|c|c|}
\hline Metal & \multicolumn{2}{|l|}{ Samples } & Standard & Upstream & Midstream & Downstream \\
\hline \multirow[t]{5}{*}{$\mathrm{Cu}(\mathrm{ppm})$} & \multicolumn{2}{|l|}{ Water } & $0.05 \mathrm{ppm}^{\mathrm{a}}$ & $0.0044 \pm 0.0010$ & $0.0476 \pm 0.0016$ & $0.0069 \pm 0.0016$ \\
\hline & \multicolumn{2}{|l|}{ Sediment } & $\begin{array}{l}20 \mathrm{ppm}^{\mathrm{b}} / \\
100 \mathrm{ppm}^{\mathrm{c}}\end{array}$ & $53.85 \pm 8.06$ & $55.14 \pm 0.14$ & $56.98 \pm 1.66$ \\
\hline & \multirow{3}{*}{ C. macrocephalus } & Liver & $20 \mathrm{ppm}^{\mathrm{d}}$ & $18.50 \pm 6.58$ & $15.72 \pm 0.21$ & $7.89 \pm 0.69$ \\
\hline & & Gills & $20 \mathrm{ppm}^{\mathrm{d}}$ & $6.46 \pm 2.02$ & $5.91 \pm 0.62$ & $5.60 \pm 0.85$ \\
\hline & & Muscle & $20 \mathrm{ppm}^{\mathrm{d}}$ & $2.50 \pm 0.10$ & $2.75 \pm 0.52$ & $2.05 \pm 0.12$ \\
\hline \multirow[t]{5}{*}{$\mathrm{Pb}(\mathrm{ppm})$} & \multicolumn{2}{|l|}{ Water } & $0.05 \mathrm{ppm}^{\mathrm{a}}$ & $0.0100 \pm 0.0015$ & $0.0075 \pm 0.00185$ & $0.0151 \pm 0.00256$ \\
\hline & \multicolumn{2}{|l|}{ Sediment } & $\begin{array}{l}20 \mathrm{ppm}^{\mathrm{b}} / \\
100 \mathrm{ppm}^{\mathrm{c}}\end{array}$ & $27.65 \pm 1.28$ & $33.99 \pm 6.10$ & $49.25 \pm 4.99$ \\
\hline & \multirow{3}{*}{ C. macrocephalus } & Liver & $2 \mathrm{ppm}^{\mathrm{d}}$ & $<\mathrm{MDL}$ & $<\mathrm{MDL}$ & $4.25 \pm 0.65$ \\
\hline & & Gills & $2 \mathrm{ppm}^{\mathrm{d}}$ & $<\mathrm{MDL}$ & $<\mathrm{MDL}$ & $3.58 \pm 0.33$ \\
\hline & & Muscle & $2 \mathrm{ppm}^{\mathrm{d}}$ & $<\mathrm{MDL}$ & $<\mathrm{MDL}$ & $3.32 \pm 0.47$ \\
\hline \multirow[t]{5}{*}{$\mathrm{Zn}(\mathrm{ppm})$} & \multicolumn{2}{|l|}{ Water } & None $^{\mathrm{a}}$ & $0.0648 \pm 0.0312$ & $0.0499 \pm 0.0403$ & $0.0527 \pm 0.0190$ \\
\hline & \multicolumn{2}{|l|}{ Sediment } & $\begin{array}{l}50 \mathrm{ppm}^{\mathrm{b}} / \\
300 \mathrm{ppm}^{\mathrm{c}}\end{array}$ & $100.45 \pm 6.08$ & $96.52 \pm 3.60$ & $111.30 \pm 7.63$ \\
\hline & \multirow{3}{*}{ C. macrocephalus } & Liver & $50 \mathrm{ppm}^{\mathrm{d}}$ & $62.83 \pm 10.97$ & $87.92 \pm 3.76$ & $54.47 \pm 2.34$ \\
\hline & & Gills & $50 \mathrm{ppm}^{\mathrm{d}}$ & $56.01 \pm 0.70$ & $61.69 \pm 5.14$ & $54.98 \pm 2.75$ \\
\hline & & Muscle & $50 \mathrm{ppm}^{\mathrm{d}}$ & $20.87 \pm 1.08$ & $20.70 \pm 1.04$ & $20.17 \pm 0.66$ \\
\hline
\end{tabular}

Notes: Values are Mean \pm Standard Deviation

a Philippines' DENR DAO 34 Series of 1990

b Kloke's Guideline Values for the Soil (Normal Background Levels)

c Kloke's Guideline Values for the Soil (Maximum Allowable Limit)

d Maximum Allowable Limit for Trace Metals (Europe)

MDL $=$ Method Detection Limit 
Copper, Lead and Zinc Concentration in Water, Sediments and Catfish (Clarias ....

Table 3. Biota-Sedimemt Accumulation Factor (BSAF) of C. macrocephalus from Butuanon River.

\begin{tabular}{|l|l|l|l|l|}
\hline \multicolumn{1}{|c|}{ Stations } & \multicolumn{1}{c|}{ Cu } & \multicolumn{1}{c|}{ Pb } & \multicolumn{1}{c|}{ Zn } \\
\hline Upstream & $0.453 \quad$ & n.c. & 1.440 \\
\hline Midstream & 0.442 & n.c. & 1.819 \\
\hline Downstream & 0.270 & 0.228 & 1.210 \\
\hline
\end{tabular}

n.c. $=$ not computed as it is below MDL

The bioavailabilty of metals is often affected by a variety of parameters; among considered in this study are the metal concentration in water, sediment, organic matter content and percent silt. Using these variables, analysis was employed to determine what greatly affects the bioconcentration of $\mathrm{Cu}$ in the $\mathrm{C}$. macrocephalus from Butuanon River. The derived regression equation $(\mathrm{R}=89.9)$ affecting copper concentration in C. macrocephalus is shown below:

$$
\mathrm{Cu}_{(\text {Fish })}=1.36+0.00800 \mathrm{Cu} \text { (Sediment) }-67.1 \mathrm{Cu}_{(\text {Water) }}-0.0288 \text { (Organic Matter) }
$$

Moreover, due to the unavailability of data on $\mathrm{Pb}$ values of the upstream and midstream stations, a regression equation could not be established. Regression was run for $\mathrm{Zn}$ but neither of the parameters tested is a good predictor of $\mathrm{Zn}$ concentration in Butuanon River.

\section{Discussion}

A higher $\mathrm{pH}$ value promotes the precipitation of metals, which subsequently settles to the sediments [21] in fact when the $\mathrm{pH}$ values of soils ranged from 5.0 to 7.0, the mean values of extractable metals are approximately the same [22] Since there is no significant difference across stations and the $\mathrm{pH}$ are neutral, $\mathrm{pH}$ is not a factor in the bioavailability of metals in the case of Butuanon River.

Sediments have a general downhill tendency moving towards floodplains, deltas and eventually delivered to the sea.[22] and this is shown in Butuanon River (Table 1). Siltation in Butuanon River though is aggravated by a number of human activities that increase sedimentation rate. These are run off are due to poor agricultural practices, channel straightening, overgrazing of river and stream banks, and clearing of streamside vegetation, construction and construction related activities such as dredging and quarrying [23].

Butuanon River shows a typical distribution of organic matter (Table 1). Organic matter is usually carried along with the silt in a downhill direction and could be increased by the effluents from the residences and from food and feed manufacturing facilities [24] that are notably abundant at midstream and downstream stations. The organic matter can actually be both beneficial and detrimental. Detrimental in such a way that it may increase BOD since more organisms would require oxygen to proceed with the process of decomposition [2]. On the other hand, it could be beneficial in such a way that organic matter can sorb trace elements and reduce contamination in the water and organisms [2].

The result clearly suggests the occurrence of anthropogenic introduction of $\mathrm{Cu}$ in Butuanon River (Table 2). The likely major source of $\mathrm{Cu}$ in Butuanon River could be at the headwaters of Butuanon River as no statistical difference were observed among the three sampled stations. The above findings could be attributed to the widespread use of fungicides in the mango plantations and other agricultural crops that abound the upper portions of Butuanon River. There is a heavy use of fungicides with copper oxychloride and copper hydroxide as active ingredients in the Philippines [25]. These pesticides come in different trade names and may be widely used among mango plantations located prior to the upstream station. Major diseases that affect mango crop production in the Philippines are all caused by fungi and are more often treated with copper based fungicides [26].

Findings as shown in Table 2 suggest that there is a source of $\mathrm{Pb}$ even before the upstream station and is further aggravated at midstream and downstream stations. Non-point sources in the upstream could have contributed to the $\mathrm{Pb}$ load such as the deposition from the atmosphere from petrol or industrial sources and old paints [6]. This could be further amplified by anthropogenic activities midstream and downstream. These activities are caulking, soldering and use of paints and pigments that are common among furniture industries. The paint-thinner production facility near midstream station may also contribute to the $\mathrm{Pb}$ concentration in the river [12]. In addition, the concrete mix facilities present along the Butuanon River may also have contributed since $\mathrm{Pb}$ is naturally present in cements [27]. Gas stations and car service stations found midstream could have also contributed to $\mathrm{Pb}$ concentration in the river. Lead in this type of industry is usually from battery electrolytes, paints and thinners [28]. Furniture industries and gas stations are also present downstream in addition to the used-oil treatment facility that could be a unique source of $\mathrm{Pb}$ as opposed to other sampling stations. Used oil may contain metals particularly $\mathrm{Pb}$ [29]. Adjacent potential sources of $\mathrm{Pb}$ may be present midstream but it was found to have smaller $\mathrm{Pb}$ concentration both in water and sediment. This is primarily because once a metal is discharge into the river, it is usually carried by the water and it settles several kilometers downstream [30]. This process could explain why $\mathrm{Pb}$ concentration is significantly higher downstream. 
Potential sources of $\mathrm{Zn}$ such as galvanized metal production and brass and bronze alloy production in the furniture industries [12] are all present midstream (Table 2). However no significant difference across the sampling stations were noted although a slight increase is observed downstream possibly caused by four galvanized iron facilities where zinc is used as a coating to prevent corrosion [31]. Additional sources could be through the settlement of $\mathrm{Zn}$ metal transported by the water [34]. Overall, results of this study indicate that $\mathrm{Zn}$ is a natural component in the sediment of Butuanon River since it is fairly abundant upstream at $96.157 \mathrm{ppm}$ despite the absence of identified source in the area. In a study [21], $\mathrm{Zn}$ was found to be an abundant trace metal in all aquatic ecosystems that could range at varying concentrations even as high as $261 \mathrm{ppm}$. This is further supported by a separate study by [2] claiming that Zn may exist naturally between 25 to $200 \mathrm{ppm}$.

Contaminants are usually discharged at low levels but long-term partitioning to the sediment could result to the accumulation of high load of pollutants [35]. This process explains why heavy metal concentration in the water is extremely low in contrast to that of the sediments. The fate of metals is also affected by other parameters such as silt and organic matter concentration.

$\mathrm{Cu}$ and $\mathrm{Zn}$ are essential for the metabolism of organisms but can become toxic in high concentrations due to their influence in the redox balance of the cell while $\mathrm{Pb}$ has no clear biological function and exposure to them can impair enzymatic activity, reproductive capacity and development [4].

The concentration for $\mathrm{Cu}$ in catfish (C. macrocephalus) across stations is within the European standard at 20ppm but it shows a decreasing trend for samples downstream (Table 2). An earlier study shows that $90 \%$ of $\mathrm{Cu}$ is immobilized as it is adsorb in the surface and forms complexes with organic matter [20] and this could explain the decrease in $\mathrm{Cu}$ concentration in fishes sampled from an organic matter rich downstream station. While, the detection of $\mathrm{Pb}$ only in catfishes sampled downstream is a clear indication that this station has a higher degree of contamination consistent with the trend of $\mathrm{Pb}$ concentration values in the water and sediment of Butuanon River. The sampled fish downstream clearly accumulated $\mathrm{Pb}$ from its ambient environment making it unsafe for human consumption. The $\mathrm{Zn}$ concentration across stations passed the European standard at 50ppm likewise did not differ significantly which is consistent with the $\mathrm{Zn}$ concentration values of water and sediment as well. This further indicates that $\mathrm{Zn}$ may be naturally present in the Butuanon River. However, among the three organs of the $C$. macrocephalus, muscle is found to be significantly lower $(\mathrm{p}<0.05)$ as compared to gills and liver. The $\mathrm{Zn}$ concentration values in the muscle of C. macrocephalus are within the $50 \mathrm{ppm}$ standard of Europe but both liver and gills have failed. Though $\mathrm{Zn}$ concentration in fish organs is indicative of the contamination level in Butuanon River, the threat it poses is less serious as liver and gills of C. macrocephalus are rarely consumed.

In all metals and sampling stations, the order of concentration in the organs follow this trend liver $>$ gills $>$ muscle (Table 2). It should be pointed out that the liver of the fish plays a primary role in the metabolism and excretion of xenobiotic compounds with morphological alterations occurring in some toxic conditions [33]. The concentration of these metals in the gill tissues of catfish (C. macrocephalus) could possibly be related to the fact that they are the main sites for pollutant uptake due to the large surface that is in contact with environment and the very thin barrier separating the external and internal media of the animal [34]. On the other hand, the muscles of the catfish having contained the lowest levels of heavy metals could be due to being an inactive site in accumulating metals [35].

As shown in Table 3, the BSAF values obtained in this study are in an expected order since $\mathrm{Zn}$ and $\mathrm{Cu}$ are both essential metals while $\mathrm{Pb}$ is a non-essential metal [36]. The BSAF values for $\mathrm{Cu}$ and $\mathrm{Zn}$ obtained in this study follow in the same order with another carnivorous fish, S. thumbergi [37]. However, the BSAF values are relatively smaller compared to other studies implying that the degree of accumulation in the C. macrocephalus is not that high as compared to other polluted aquatic ecosystems [37,38]. In a previous study [43,8], $\mathrm{Pb}$ and $\mathrm{Zn}$ had a BSAF value of 1.72 and 4.96 respectively for Chrysichthys sp. and 2.59 and 7.48 respectively for Tilapia sp. BSAF value for $\mathrm{Cu}$ could also reach as high as 11.2 [37]. Measured BSAFs above or below 1 to 2 are entirely reasonable for fish [39] as there are solid mechanistic reasons why fish should not be in equilibrium with their sediments. The fish BSAF values incorporates wide ranges of influences including biomagnification due to the trophic level of the fish, sediment-water column chemical disequilibrium, the diet of the fish and its underlying food web, the fish's foraging range and chemical metabolism within the fish and its food web [42].

The regression equation established in this study confirms that an increase in the $\mathrm{Cu}$ content in the sediment will increase $\mathrm{Cu}$ concentration in the $C$. macrocephalus that could be explained by the ecology of the fish being a burrower and a bottom feeder [4]. The water and percentage organic matter with its negative values suggest that it reduces $\mathrm{Cu}$ in the fish. Copper tend to bind on the surface area of organic matter instead of becoming bioavailable to the organism [14]. Overall, this equation further supports why $\mathrm{Cu}$ concentration in sampled fish downstreamn is significantly lower. A regression equation could not be established for Zn since its concentration in the tissues does not necessarily follow a positive relationship with the metal in the soil [40]. Furthermore, it should be noted that $\mathrm{Zn}$ is potentially naturally present in Butuanon River as confirmed by this 
study. Zinc exists as a residual fraction means that bioavailability and remobilizability may take time under normal conditions [6].

\section{Conclusion}

Anthropogenic introduction of $\mathrm{Cu}$ and $\mathrm{Pb}$ in Butuanon River could be attributed to industrial and agricultural activities rampant in the area while $\mathrm{Zn}$ may be naturally present in Butuanon river since this is within the normal level for an aquatic ecosystem. The introduction of these metals into the water and sediments has definitely led to the accumulation of these metals in C.macrocephalus. It is clear that the C.macrocephalus fished downstream is not safe for human consumption due to the toxic concentration of $\mathrm{Pb}$. It is recommended therefore that catfishes caught downstream should not be consumed. Further, it is recommended that continuous monitoring of Butuanon River should be established to control an increased loading of pollutants into the water and sediments and in effect prevent further accumulation of metals in fishes especially in the less polluted, elevated areas of the river.

\section{Acknowledgement}

This study was supported by the Department of Science and Technology-Philippine Council for Aquatic and Marine Resources Department and the University of San Carlos.

\section{References}

[1]. D. Manahan, Fundamentals of Environmental Chemistry, $2^{\text {nd }}$ ed, Lewis Publishers, USA 2000.

[2]. G. Pierzynski, J.T. Sims and G. Vance, Soils and Environmental Quality, Taylor and Francis, USA 2005.

[3]. A. Love and C. Babu, in Trace elements in the environment: Biogeochemistry, Biotechnology and Bioremediation (Eds.: M. Prasad, K. Sajwan, R. Naidu), CRC Press, Florida, USA 2006, p. 659-687.

[4]. Azevedo, J.S., J.E.S. Sarkis, M.A. Hortelleni, Are Catfish (Arridae) Effective Biondicators for Pb, Cd, Hg, Cu and Zn? Water Air Soil Pollut 2012, 223, 3911-3922.[5] Y. Sanayei, I. Norli, S.M. Talebi, Determination of heavy metals in Zayandeh rood river, Isfahan-Iran, World Appl. Sci. J 2009, 6 (9), 1209- 1214.

[5]. C. Mendoza, L. Suico, Trace metal concentration in four selected rivers of Metro, Cebu, Philippines; A baseline study, in Southwatch '95: A conference on environmental research and resource management in the Visayas and Mindanao regions, Cebu, Philippines 1995. p. 79-91.

[6]. P. Nazareno, An assessment of the water quality of the Butuanon River in Mandaue City, Cebu, UPV J of Nat Sci 2000, 5, 87-96.

[7]. A. Muego, Butuanon River Rehabilitation: A test case for the Clean Water Act Implementation in Metro Cebu, Philippines, in Regional Conference on Urban Water and Sanitation in South East Asian Cities, Bangkok, Thailand 2006, p. 313-328.

[8]. .P. Bongo, Biocriteria and system analysis in the assessment of human impact in Butuanon River, Philippines; Its implication to sustainable watershed management: A case study of Btuanon River Watershed, Cebu Province, Lund University Master's Thesis 1998.

[9]. R. Ancog, G.B. Andrade, R.B. Miasco, M.F. Ortiz, Water Quality and Diversity of Macroinvertebrate Species in Rivers of Cebu City, Philippines, Phil Scientist 2010, 47, p. 27-45

[10]. M.N.V. Prasad, in Trace elements in the environment: Biogeochemistry, Biotechnology and Bioremediation (Eds.: M. Prasad, K. Sajwan and R. Naidu), CRC Press, Florida, USA 2006. p. 523- 547.

[11]. A. Violante, G. Krishnamurti, M. Pigna, in Biophysical-Chemical Processes of Heavy Metals and Metalloids in Soil Environments (Eds.: A. Violante, P. Huang and G. Gadd), Wiley-Interscience, USA 2005. p. 169-213.

[12]. A. Eaton, L. Clesceri, E. Rice, A. Greenberg. Standard methods for the examination of water and wastewater, $21^{\text {st }}$ ed., APHA, AWWA, and WEF, Washington DC, 2005.

[13]. R. Lacatusu, Appraising levels of soil contamination and pollution with heavy metals, European Soil Bureau-Research Report No. 4, Italy 1998.

[14]. D. Boehknke, R. Del Delumyea, Laboratory Experiments in Environmental Chemistry (USA: Prentice Hall, 2000).

[15]. R. Vinodhini, M. Narayan, Bioaccumulation of heavy metals in organs of fresh water fish Cyprinus carpio (Common carp), Intl Jour of Envi Sci and Tech 2008, 5 (2), 179-182.

[16]. F.M.J. Brown, P.W. Balls.1997. Trace metals in fish and shellfish from the Scottish Waters. Scottish Fisheries Report $1997,60$.

[17]. Berandah, F.E., Y.C. Kong and A. Ismail, Bioaccumulation and Distribution of Heavy $\mathrm{Metals}(\mathrm{Cd}, \mathrm{Cu}, \mathrm{Fe}, \mathrm{Ni}, \mathrm{Pb}$ and $\mathrm{Zn})$ in the Different Tissues of Chicoreus capucinus Lamarck (Mollusca: Muricidae) Collected from Sungai Janggut, Kuala Langat, Malaysia, Environment Asia 2010, 3 (1), 65-71

[18]. Exponent (Engineering and Scientific Consulting), Review of Bioaccumulation Methods for Fish and Shellfish, Washington State Department of Ecology, USA 1998.

[19]. A. Abdel-Satar, Quality of Nile Sediments from Idafo to Cairo. Egyptian J of Aqua Res 2005, 31(2), $182-199$.

[20]. Zeng, F., S. Ali, H. Zhang, Y. Ouyang, B. Qiu, F. Wu and G. Zhang, The influence of pH and organic matter content in paddy soil on heavy metal availability and their uptake by rice plants. Environmental Pollution 2011, 159, 84-91.

[21]. Peng, J. , S. Chen and P. Dong. Temporal variation of sediment load in the Yellow River basin, China, and its impacts on the lower reaches and the river delta, Catena 2010,83 (2-3), 135-147.

[22]. J.S. Baron, N. L. Poff, Sustaining Healthy Freshwater Ecosystems, UCWR Water Res Update Issue 2004, 127, 52-58

[23]. P. Servais, J. Garnier, N. Demarteau, N. Brion, G. Billen, Supply of organic matter and bacteria to aquatic ecosystems through waste water effluents, Water Research 1999, 33, 3521-3531.

[24]. FPA (Department of Agriculture-Fertilizer and Pesticide Authority), List of registered agricultural pesticides as of January 2010, Quezon City, Philippines 2010, p. 64.

[25]. DA-HVCCP (Department of Agriculture-High Value Commercial Crops Program), Techno-Guide For Mango In The Philippines, Quezon City, Philippines 2001, p. 44.

[26]. Y. Dosho, Developement of a Sustainable Concrete Waste Recycling System-Application of Recycled Aggregates Concrete Products by Aggregate Replacing Method, J of Advanced Concrete Tech 2007, 5 (1), 27-42. 
[27]. J. Porst, Environmental Monitoring Handbook: Documentation on monitoring and evaluating environmental impacts, Federal Ministry for Economic Cooperation and Development, Germany 2000, p. 50.

[28]. US EPA (Unites States Environmental Protection Agency), Final Business Workbook for Drinking Water Protection, Horsley and Witten, USA 2002, p. 104.

[29]. N. Milenkovic, M. Damjanovic, M. Ristic, Study of heavy metal pollution in sediments from the Iron Gate (Danube River), Serbia and Montenegro, Polish J of Envi Studies 2005, 14 (6), 781-787.

[30]. Akamphon, S., S. Sukkasi, Y. Boonyongmaneraat, Reduction of Zinc Consumption with Enhanced Corrosion Protection in Hot-Dip Galvanized Coatings: A Process-Based Cost Analysis, Resources, Conservation and Recycling 2012, 59, 1-7.

[31]. K. Binnin, D. Baird, Survey of heavy metals in the sediment of the Swartkops River and Estuary, Port Elizabeth, South Africa, African J Online 2001, 27(4), 461-466.

[32]. E. Rocha, R.A.F. Monteiro, in Ichtylogy: Recent Research Advances, (Ed.: D.N. Saksena) Science Publishers, Enfield, New Hampshire 1999, p. 321-344.

[33]. T. Murugan, An inventory of the Algal flora of Temple tanks at Kanchipuram, Indian Hydrobiology 200811 (1), 99 - 102.

[34]. M. Bahnasawy, A. Aziz Khidr, N. Dheina, Seasonal Variation of Heavy Metals Concentration in Mullet Mugil cephaulus and Liza ramada (Mugilidae) from Lake Manzala, Egypt J of Applied Science Research 2009, 5(7), 845-852.

[35]. W. Landis, M. Yu, Introduction to Environmental Toxicology: impacts of chemicals upon ecological systems ( Boca-Raton, Florida :CRC Press, 2004)

[36]. M. Nakayama, Y. Ikenaka, K. Muzandu, K. Choongo, B. Orazlany, H. Teraoka, N. Mizuno, Naoharu, M. Ishizuka, Heavy Metal Accumulation in Lake Sediments, Fish (Oreochromisniloticus and Serranochromis thumbergi), and Crayfish (Cherax quadricarinatus) in Lake Itezhi-tezhi and Lake Kariba, Zambia, Arch Environ Contam Toxicol 2010, 59 (2), 291-300.

[37]. A.A. Adeniyi, K.A. Yusuf, O.O. Okedeyi, Assessment of the exposure of two fish species to metals pollution in the Ogun river catchments, Ketu, Lagos, Nigeria, Environ Monit Assess 2008, 137, 451-458.

[38]. L. Burkhard, Estimation of Biota Sediment Accumulation Factor (BSAF) from Paired Observations of Chemical Concentrations in Biota and Sediment, United States Environmental Protection Agency (US EPA) Ecological Risk Assessment Support Center Cincinnati, USA 2009.

[39]. T. Kamitani, N. Kaneko. Species-specific metal accumulation patterns of earthworms on a floodplain in Japan, Ecotox and Envi Safety 2005, 66, 82-91. 